2009-01-01

\title{
Corruption and Development: The Armenian Case
}

Phillip J. Bryson

phil_bryson@byu.edu

Sevak Tsaturyan

Follow this and additional works at: https://scholarsarchive.byu.edu/facpub

Part of the Economics Commons

\section{Original Publication Citation}

Tsaturyan, S. and Bryson, P.J. (29) 'Corruption and development: The Armenian case', International Journal of Economic Policy in Emerging Economies, Vol. 2, No. 4, pp. 356-371. http://www.inderscience.com/browse/index.php?journalID=219

\section{BYU ScholarsArchive Citation}

Bryson, Phillip J. and Tsaturyan, Sevak, "Corruption and Development: The Armenian Case" (2009). Faculty Publications. 148.

https://scholarsarchive.byu.edu/facpub/148 
Corruption and Development: The Armenian Case

Sevak Tsaturyan

and

Phillip J. Bryson

Brigham Young University

Contact Information

Phillip J. Bryson

Douglas and Effie Driggs Professor of Economics

Marriott School

Brigham Young University

Provo, Utah 84602

Tel. 801 422-2526

phil_bryson@byu.edu 


\begin{abstract}
To determine the relationship between corruption and economic growth variables, we first undertake a general analysis of those relationships for 39 countries over an eleven year period. Since the data on corruption specific to Armenia are insufficient for an econometric analysis, we undertake a case study of that country to illuminate the relationships determined by the empirical analysis. We find corruption to be a hindrance for overall economic performance, since there is a strong negative correlation between corruption indices and real per capita GDP. Regressing real Foreign Direct Investment on corruption, however, we found no strong relationship between the two. Nor is there evidence that high levels of corruption limit international trade. Imports of goods and services increase as corruption does. As a country's business increases in terms of foreign trade and FDI, increased opportunities are provided for corrupt officials.
\end{abstract}

Since 2000, Armenia's corruption indices have declined consistently, showing poor performance, and its ranking among other nations has continued to fall. Nevertheless, FDI has continued to increase in that period of strong economic growth. Other performance indicators demonstrate a very healthy macro economy not apparently troubled with the effects of corruption.

\title{
JEL Classification: O1, O57, D73, P27, P33.
}




\section{Corruption and Development: The Armenian Case}

\section{Introduction}

Corruption takes its toll on almost every aspect of governance and human life. It is mostly viewed as a diversion of scarce resources into unproductive channels and as a brake on economic development. Developing countries seem particularly vulnerable to its negative influence, to the grasping hand that intimidates progress. The achievements of a reduction in poverty and of sustained economic growth are viewed as being dependent upon victory in the battle with corruption. Armenia is among those countries engaged in this struggle and is illustrative of the difficulties and complexities they experience.

Drawing on the data and analyses of corruption in general, we wish to see what lessons there are for Armenia in particular. We are interested in the impact of corruption on Foreign Direct Investment (FDI), on general economic development (GDP growth), and on imports of goods and services. These relationships can be tested quantitatively, since in recent years indices of corruption have been developed and applied to numerous countries. Although little work has been done in the application of such indices to the Armenian case, empirical work on other countries with similar corruption problems can certainly provide insights that will apply to Armenia.

Section II will review previous scholarly findings on the issue of corruption generally. After reviewing pioneering studies on Foreign Direct Investment (FDI), growth and corruption, we present our own investigation of the relationship between corruption and economic performance in section III. Section IV will suggest some applications of these findings to a transition country like Armenia. The concluding summary is presented in section V. 


\section{Scholarly Perceptions of Corruption and its Impact}

Corruption, one of the oldest of all commercial activities, has been defined by Kaufmann and Gray (1998) as the misuse of public office for private gain, a practice that can be very costly for a developing economy. The problem of corruption was addressed early by Plato and Aristotle, and in our own time by scholars such as Bhagwati (1982), Krueger (1974), Ackerman (1978), and Tullock (1989). Its threat to international markets has been subject to empirical analysis only in the last two decades (see Abed and Gupta, 2002).

In the trend of recent years toward a freer world economy and financial markets, corruption has been viewed as one of the greatest challenges facing the globalization of international business. Glynn, Kobrin, and Naim (1997) have argued that the increased attention to corruption as a global policy issue is a result of both perceived and real increases in the phenomenon. Although the extent of corruption has probably increased in some places, in many countries its apparent increase is simply a discovery of previously overlooked issues exposed by recently-empowered media and voters.

Several economists have suggested that corruption could enhance economic efficiency by "greasing the wheels" of burdensome bureaucracies (Leff, 1989; Huntington, 1968). The majority, however, argue that corruption reduces investment and slows economic growth for a variety of reasons. First, due to the unreported nature of bribery, its effects deny treasuries of tax revenues. Tsaghikyan (2002) argues that the loss of such tax revenues accompanies the non-reporting of normal business transactions that otherwise would have produced additional tax revenues from construction permits, sales taxes, import and export taxes, and so on.

Public services in corrupt countries are often enjoyed by those who pay bribes, while services are denied to those who do not. The result is an uneven service distribution with inferior or no services for a good share of the citizenry. This inefficient allocation of resources distorts 
government expenditures and reduces the share of public spending, for example, on education. Mauro (1997) argues that reduced spending on public education impacts a country's growth potential by reducing human capital formation and exacerbating income inequality. Bribes also enable service providers, such as contractors for public infrastructure projects, to ignore established standards, offering substandard goods or services (Cheem, 1997; Dearden, 2000; and Aristidis, 2003). Goodspeed, Martinez-Vazquez and Li (2006) used the determinants of FDI inflows in two unbalanced panel data sets of forty-seven countries from 1995-2002 and thirty-seven countries from 1996-2002 to examine investments in infrastructure and consumption. Their conclusions were that lower taxes, lower corruption, and better infrastructure attract FDI and that government consumption expenditures negatively impact FDI inflows.

In terms of cross-national studies, the International Monetary Fund has sponsored much empirical research (see, for example, Mauro, 1997). Mauro found that when the corruption indicator for a country declines by two points (on a ten point scale with 0 for the most corrupt and 10 for the least corrupt), the GDP decreases by half a percent and investment decreases by four percent. What really suffers is public investment; government expenditure on education, for example, declines by half a percentage point for each two-point increase in the corruption index. Mauro's conclusions find some support from Lambsdorff (2003), who found significant quantitative relationships between corruption indices, FDI inflows and GDP growth.

Finally, Gupta, Davoodi, and Alonso-Terme (1998) find that in countries where corruption is extensive, it severely reduces income growth for the poor. Gray and Kaufmann (1998) find that in such countries the rate of investment is only half of that in low-corruption countries. Abed and Gupta (2002) argue that corruption negatively impacts economic growth through the public finances, exacerbating poverty and income inequality, and misallocating provisions for social services. 
Contrasting research by Friedman et al (2000) suggests that high levels of corruption do not materially affect business activity in a country, but merely drive it underground. Based on a crosscountry analysis of 69 countries, they argue that economic slowdown occurs because underground business activity denies the government of tax revenue, producing smaller governments less able to provide infrastructure and public services. It is not clear how great an impact such impaired public sectors could have on FDI, but one should not expect that it would be positive.

Friedman et al ignore the possibility that reduced public services impact FDI, assuming that the effect is insignificant and concluding therefore that FDI is not affected by corruption. Habib and Zurawicki (2001) support this conclusion. They posit a more complex relationship between corruption and FDI, citing the examples of China, Brazil, Thailand, Mexico and Argentina to demonstrate that, despite the high corruption levels identified by the Corruption Perceptions Index, those countries have all received substantial FDI inflows.

Wacziarg (2002) argues that more open economies have better macroeconomic management, which supports the conclusion of Ades and Di Tella (1999) that higher ratios of imports to GDP are associated with lower indicators of corruption across countries, a point which will be elaborated below.

Generally speaking, there seems to be a consensus that corruption negatively impacts economic progress, especially with regard to the developing economies. The controversial issue is whether this negative influence results from the loss of Foreign Direct Investment inflows into the corrupt, developing country. It may be logical to assume that multinational corporations will be inclined to avoid investing in corrupt economies due to factors mentioned above. We will attempt to determine whether more corrupt countries are in fact apt to receive smaller FDI inflows than the less corrupt ones. That information may suggest whether multinational enterprises (MNEs) pay much heed to the Corruption Perception Index of a potential investment target. First, it would be 
important to know whether those investing in or doing business with corrupt economies simply consider the cost of bribes as an inconvenient but rather normal transactions cost. Second, from the perspective of this study, we wish to add empirical evidence as to whether more open economies (measured by the ratio of imports to GDP) are less corrupt than the more autarkical ones. Can corruption be viewed as a sort of mercantilistic inhibitor of imports because less corrupt countries enjoy a greater volume of imports? These are the questions we wish to address.

\section{Corruption and Economic Performance}

We attempt here to determine the relationship between corruption and economic growth. We will also attempt to clarify the econometric relationship between corruption indices and both foreign direct investment and foreign trade. Prior studies have regressed indicators such as GDP growth on the available indices of corruption. Despite advances in data collection and in research technologies, developing quantitative indices of corruption has been difficult, especially given the secretive nature of the phenomenon in question. ${ }^{1}$

We begin by reviewing two important studies by Paulo Mauro $(1995,1997)$ and Johann Lambsdorf (2003) summarizing the apparent general consensus. These studies test the assumption that corruption has a significant and negative impact on economic performance both of transition economies and of more developed countries. The assumption is not unreasonable. Corruption likely distorts resource allocation in the public and private sectors, diverting public revenues into private hands. It increases transactions costs and uncertainty, misallocates talent and puts considerable resources into rent-seeking activities, distorts technology choices, distorts free market

\footnotetext{
${ }^{1}$ Two organizations, Transparency International and Political Risk Service, Inc., have developed measures to quantify corruption. Their indices rank countries from 0 to 10 according to the extent of their corruption, with 0 being most corrupt and 10 being least. The World Bank, International Monetary Fund, Transparency International and various other institutions have sponsored an extensive amount of research generally featuring regressions of economic performance data on the corruption indices these organizations produce.
} 
outcomes, motivates firms to go underground (undercutting the state's ability to raise revenues), leads to higher tax rates levied on fewer taxpayers, reduces the state's ability to provide essential public goods and assure the rule of law, renders property and contract rights insecure and unstable; and so on. In summary, the expected outcome of a corrupt economy is the slowdown of that economy's growth.

It is under this expectation that Mauro performed a cross-country analysis of the effects of corruption on growth, investment and government expenditures. He utilized indices of corruption from Political Risk Services' International Country Risk Guide (ICRG), and Business International, now merged with the Economist Intelligence Unit (Mauro, 1997, p. 88). This index measures the likelihood of the acceptance of bribes by government officials. It is based on the observations of public, government and business officials. The data set is fairly large, consisting of 26 years of indices from 1960-85.

Regressing the 1960-85 average annual per capita GDP growth on the corruption index, Mauro found a significant correlation. He concluded that a one-standard deviation (2.38 point) improvement in the corruption index is associated with a greater than 0.5 percentage point increase in the per capita growth rate. If a country improved its corruption measure (or score) from 6 to 8 , therefore, its annual per capita GDP growth would increase by nearly half a percentage point. Alternatively expressed, for every one-point improvement in the corruption index real GDP changes by a little more than $0.2 \%$.

Lambsdorff (2003) finds a greater response of growth performance to change in the corruption index he helped Transparency International develop in 1995. This index is compiled with the same 10 point format (10 being for the least corrupt countries with the high score implying anti-corrupt institutions). It ranks more than 150 countries in terms of corruption as perceived by expert assessment and opinion surveys. Lambsdorff concludes that a one point increase in 
corruption reduces GDP by 4 percent, which is eighteen times as great as Mauro's projected 0.22 percent change. For both studies, of course, the correlation is statistically significant.

\section{Foreign Direct Investment and Corruption}

According to consensus views, corruption hinders economic development by driving foreign direct investment away from a country. This seems logical given the distorting effects of bribe payments on international competition and trade flows. United States firms have been especially concerned about international corruption and they have lobbied for anti-corruption measures at major world organizations such as the IMF and the World Bank. Former US Trade Representative and Commerce Secretary Michael Kantor referred to corruption as "a virus threatening the health of the international trading system" (see Elliott, 1997, p. 198).

United States legislation is quite unusual in prohibiting the involvement of US Multinational Enterprises in illegal operations overseas. Some claim that the Foreign Corruption Practice Act (FCPA) of 1997 represents a "competitive disadvantage" for American MNEs, some of which must compete with firms from countries that not only fail to sanction corruption, but even encourage bribes to win contracts abroad. This issue of "competitive disadvantage" has motivated many firms to lobby for anti-corruption awareness measures with the World Bank, the IMF and the International Court of Justice, (ICJ).

Using data mentioned above, Mauro (1997, p. 91) has investigated the relationship between corruption indices, growth and Foreign Direct Investment (FDI). He found that as corruption declines, FDI increases by four percentage points per standard deviation (2.38) improvement in the corruption index. With each one-point change in the corruption index, investment capital inflows rise by nearly $1.7 \%$.

Figure 1 Here 
In contrast to Mauro's findings, Lambsdorff's use of Transparency International's CPI index for his regressions shows an increase of no more than $0.5 \%$ in FDI per point improvement in the corruption index as seen in Figure 1. There is, of course, a positive and significant correlation between the two variables. It should be noted that while Mauro uses Foreign Direct Investment, Lambsdorff includes net annual capital inflows as a percentage of the GDP. We note that although the specified impact of corruption on GDP growth and on FDI varies in these studies, they both conclude that corruption does to a degree act as a brake on both FDI and growth.

\section{Challenging the Hypothesis}

If corruption does in fact have an impact on economic development and FDI, that impact must be observable not only in the research of Mauro and Lambsdorff, but in any properly conducted empirical analysis. We have tested these apparently consensual hypotheses on the effects of corruption to determine the significance of the relationship between these variables. We are interested in gaining for countries for which data is available some notion of the impact of corruption. We are particularly desirous of determining the impact of corruption on Armenia, a fairly new democracy transitioning away from the central planning institutions of the Soviet Union. While the studies of the previous section conclude that a one-point change of corruption has some inverse impact on GDP or investment growth, they provide no information regarding the impact of corruption on the economic performance of developing countries over the last ten years of the transition.

For a sample of 39 countries, we have run regressions with data on various national income accounts (real GDP per capita measured at purchasing power parity, government final consumption expenditures, private final consumption expenditures, gross fixed capital formation and real GDP growth), with data on international capital flows and trade coefficients (FDI inflows, total imports, 
imports of goods and services and increases in stocks) and with CPI (Corruption Perception Index) data from Transparency International.

An analysis of eleven years of data for these sample countries (see the Appendix) establishes the quantitative relationships between the economic variables and the corruption indices utilized. All the data were in Local Currency Units (LCU) and on a per capita basis. ${ }^{2}$ Stronger econometric outcomes for regressions of data in both constant and current prices were achieved regressing yearto-year percentage changes on the corruption indices. Regressions established statistically significant relationships between the Corruption Perception Index and GDP, FDII (the Foreign Direct Investment Index), Total Imports and Imports of Goods and Services (IGAS) as a percentage of GDP. In addition, several other measurements of economic growth were included in the regressions, GFCE (Government Final Consumption Expenditure), GFCF (Gross Fixed Capital Formation), IS (Increases in stocks), and PFCE (Private Final Consumption Expenditure), but these added nothing to the analysis and require no further discussion.

Table 1 displays correlation coefficients for the nine variables tested using current prices. The repeated measure model employed reflected the measures repeated over time within each country. The four models tested show a nearly significant relationship between the Corruption Perception Index (CPI) and GDP and a strong relationship between CPI and Imports of Goods and Services. There was no significant relationship between CPI and FDII or Imports. These results show that as the CPI increases one unit, GDP increases by $0.12 \%$. The relationship is expressed by:

$$
\mathrm{GDP}=3.43+12 * \mathrm{CPI}
$$

Figure 2 presents the scatter diagram of this relationship.

\footnotetext{
${ }^{2}$ Most of the data are available on the International Monetary Fund's web site (see International Financial Statistics: www.imf.org); Foreign Direct Investment data are provided by the UN Conference on Trade and Development (see www.unctad.org).
} 
Table 1 here

Figure 2 here

Regressing Imports of Goods and Services on the CPI index shows that as CPI increases by one unit, Imports of Goods and Services will decrease by $2.68 \%$. The equation for this is:

$$
\text { IGAS }=29.09-2.69 * \mathrm{CPI}
$$

The scatter diagram is presented in Figure 3.

Figure 3 here

\section{Observations: Investing in a Corrupt Economy}

Our research confirms the first consensual hypothesis, i.e., that corruption has a negative impact on economic development. When we ran these regressions with constant prices, the relationships were less robust or were not verified. But even with constant prices, a change in the corruption perception index is highly correlated with a negative change in the growth of the country's real per capita GDP and it is statistically significant.

The second major hypothesis was that corruption drives foreign direct investors out of the country. Our results reject this hypothesis. The relationship between the corruption index and Foreign Direct Investment is negative, which would also indicate that greater FDI inflows provide greater opportunities for bribe-takers. Increased business at a certain stage of development, whether in terms of international trade or flows of foreign direct investments, provides more business for corrupt officials. But it should be noted that in the case of the relationship between the CPI and FDI shows little or no statistical significance. This statistical evidence does not cast doubt on the conclusion that while some of the more ethical firms might avoid the paying of a bribe or engaging in corrupt practices in various countries, most multinational corporations do not. Apparently, many firms do not refuse to get involved with projects in corrupt countries on moral grounds, viewing corruption essentially as an inconvenient transactions cost. A bribe can be incorporated into a cost- 
benefit analysis on the basis of which a firm can decide to proceed with a planned project, building any such payments into its budget. Presumably, as businesses enter a corrupt country and encounter demands for bribes, many will find it more costly to abandon sunk costs already invested than to pay the bribes and minimize their losses.

Kimberly Elliott (1997) provides instructive examples of such situations in an article on corruption as an international policy problem. What will be a firm's response if, at the completion of a costly building, a high-level construction ministry official threatens to have it condemned as unsafe unless a large bribe is paid? If the corporation refuses to pay the bribe, the corrupt government could confiscate the building. Corporations would generally find it less costly to pay the bribe than lose the project's sunk costs as well as the anticipated stream of revenues. In the absence of strong moral codes or strict corporate policies, the profit motive will suggest caving in to bribery demands.

\section{A Paradox: Imports of Goods and Services}

We conclude this section by asking whether more open economies (measured by the ratio of imports to GDP) are less inclined toward corruption than more autarkical ones and whether corruption can be viewed as a sort of mercantilistic inhibitor of imports.

If corruption depends on the relationships between state and society and on the ways wealth and power are held and used, of course the likelihood is greater that government officials will attempt to enrich themselves at the expense of others. A serious corruption problem likely reflects a political system that is less democratic. Although the best of democracies are not completely free of corruption, and even though some benevolent dictatorships (e.g., Singapore and Chile) have had low levels of corruption, it must be remembered that the leaders of democratic states tend to be more accountable to the citizenry. But if democracy is to hold political elites accountable to their 
constituencies, a sustainable democracy should lessen the abuses of private interests. As democratic forces become stronger, corruption would become less pervasive.

Wacziarg (2002, p. 913) argues, moreover, that the progress of more democratic and more open economies will usually produce better macroeconomic management. His point is that protectionism often appears in conjunction with other ill-advised policies, such as heavy blackmarket activity and poor macroeconomic management, and that these have negative effects on growth. This negative relationship suggests that more open countries adopt better, more open policies, indirectly promoting growth and reduced corruption.

Wacziarg's interpretation supports the argument of Ades and Di Tella (1999) that higher ratios of imports to GDP are associated with lower indicators of corruption across countries. Regressing imports as a share of the GDP on corruption indices suggest that corruption is associated with rents generated by the restrictiveness of trade. Their interpretation of competition from foreign firms is that it "reduces the rents enjoyed by domestic firms, and this reduces the rewards from corruption" (p. 988). If there are no trade barriers in place, no bribes are needed to overcome trade barriers. Following Ades and DiTella, one can conclude that corruption acts as a mere tax on imports of goods and services. Under a completely open, market economy, imports would reflect a domestic supply shortage or a failure of domestic production to meet domestic consumption demands, perhaps because the country has specialized in producing other goods in which it has a comparative advantage. In this case, any regulation of free market outcomes would prove to be inefficient. However, if government officials accept bribes from domestic producers (or even from certain foreign investors) to restrict import competition, those officials would then extract cost-increasing bribes from the foreign competition. The resultant decline in the quantity of imports demanded would result in reduced total imports as surely as under a regime of legislated 
tariffs. Under these assumptions, corruption functions as a tax similar to a protective tariff, so that greater corruption would be associated with less open economies.

As indicated above, we have tested this hypothesis by regressing import data on corruption indices in 39 countries over a period of 11 years. Surprisingly, for us, the results contradicted the accepted hypothesis. Not only does a reduction in corruption fail to produce more open trade policies; as corruption increases, imports of goods and services as a share of the GDP rise by $2.69 \%$. The equation for the relationship is IGAS $=29.09-2.69 * \mathrm{CPI}$ and the scatter diagram is presented in Figure 3 above. Using current prices for this regression yields a significant statistical relationship. We are unable to conclude that lower levels of corruption are associated with increased imports as a percentage of GDP. This reverse causation problem could, of course, be associated with the possibility of an omitted variables bias. There is no guarantee that reduced corruption, as opposed to some omitted factor or factors, is actually responsible for the unexplained variance in the imports of goods and services. At the same time, our findings tend to discourage the conclusion that corruption is a strong enough influence to affect import decisions. Apparently, the impact of corruption on import prices is negligible, representing no more than a modest transactions cost. We are inclined to doubt that reduced corruption leads to greater trade; on the contrary, increased trade simply means a bigger business base for corrupt trade officials. Where there is more business, there are more opportunities to extract bribes.

Basically the same relationship holds for corruption and foreign direct investment, although this relationship was of marginal statistical significance, as was observed above. As FDI increases, there is simply more business for corrupt officials. It may be that bribes are a ticket around the bureaucracy for foreigners wishing to do business in a corrupt country, with bribes representing lower transactions costs than those that would be required to deal with the bureaucracy. 
We are not yet prepared to rule out the traditional thinking; but failing to discover a negative relationship between corruption and imports could prove to be an important finding. Firmer conclusions will have to be sought in future research.

\section{Corruption and the Development Prospects of Armenia}

Armenia $^{3}$ is a very small country transitioning to market democracy and attempting to cope with a serious problem of corruption. It fits well into the context we have been discussing in empirical terms above. Within the last several years, guest firms operating in Armenia have expressed concern about Armenian Tax and Customs laws (Chambers of Commerce, 2003). The concern is primarily about corruption, and if it were to drive foreign investors out of Armenia, economic growth would certainly be seriously affected.

Geographically, Armenia is a small country (about the size of Maryland) bordering Azerbaijan, Georgia, Iran and Turkey. Its highland mountains, forestlands and rivers provide fertile conditions for agriculture. It is not very rich in natural resources, but there are small deposits of gold, copper, molybdenum, zinc and aluminum. Armenia's major trading partners are Germany, the Netherlands, Belgium, Russia, Israel, Iran and the US.

${ }^{3}$ For background, see the CIA World Factbook on Armenia, available at: www.cia.gov. Armenia, one of the smallest nations on the globe, prides itself on having one of the most ancient civilizations. It was one of the first nations to accept Christianity as a state religion in 301 A.D. Although one of the largest kingdoms of Eurasia for many centuries, it was defeated and conquered by the Romans, Byzantines, Arabs, Persians and finally the Ottomans. During the $11^{\text {th }}$ century the Persian-Ottoman peace treaty divided the country into two parts, the western one going to Turkey and the eastern one to the Persian Empire. The eastern part of Armenia eventually solicited the help of Tsarist Russia and yielded its sovereignty to the Tsar in 1828, becoming one of the Former Soviet Republics in 1918. The western portion of Armenia remained under the Ottoman Empire, later becoming part of Turkey. During the First World War, the Turks feared that the western Armenians would solicit the help of the Russians and eastern Armenia to wrest the majority of Turkey's northeastern lands from them. As a result, they massacred approximately 1.5 million Armenians. A very large share of Armenia's budget revenues stem from the descendents of emigrants from Turkey/Armenia who have returned to open businesses. 
In addition to its paucity of natural resources, landlocked Armenia has no trading ports. Largely due to emigration, the population has declined drastically and currently has only about three million inhabitants. Since the election of 1998, the government has become more stable and the current president has helped foster positive democratic reforms. Unemployment remains high at $31.6 \%$ with $43 \%$ of the population living below the poverty line. There is considerable income inequality: $41 \%$ of national wealth accrues to the richest ten per cent of the population. But Armenia has recently enjoyed enormous economic growth, averaging annual increases of real GDP of $14 \%$ over the last several years. The inflation rate declined from 3\% in 2003 to $0.6 \%$ in 2005 .

In August 2003, thirty-four foreign firms operating in Armenia suggested that the government should enact specific tax reforms if it desired their continued business activity in the country. In March of 2005, the European Union sent its recommendations to Armenia for improvement of its taxation and customs laws (see European Commission, 2005) and the World Bank ranked Armenia as one of the worst countries in Eastern Europe and South Asia in terms of the "quality of the rule of law" (Kaufman, 2000).

In spite of such problems, Armenia signed bilateral trade and economic agreements with 28 European and Asian Countries in 2002 (see Minasian, 2005). In 2003, in a document on EUArmenia Cooperation and the New European neighborhood policy, the Armenian government reported that its recently adopted Law on Foreign Investments establishes a more favorable environment for investors. In fact, taxes currently charged on foreign companies are five percent lower than those charged on domestic competitors (Armenian Tax, 2006), a situation designed to encourage foreign investment. A somewhat surprising improvement is the level of gross fixed investment in Armenia today. It has risen to $21.4 \%$ of the GDP, which is the highest rate Armenia has ever had. Khachatrian (2006) cites the National Statistics Service in reporting Armenia's dramatic 74.5 percent increase in FDI since 2003. 
It is interesting and potentially very important that Khachatrian attributes the boom in foreign direct investment to the economic interests and activities of "the far-flung Armenian Diaspora." Our analysis above led us to the conclusion that the relationship between Foreign Direct Investment and the corruption indices is not a negative one. We are inclined to the interpretation that increased international trade and investment simply provide greater opportunities for corrupt officials. We also believe that this helps explain the situation in Armenia, where corruption at the moment seems to be worsening while trade and FDI continue to boom. But to the extent that these investments come from Armenians interested in the future of their homeland, we recognize that Armenia's development activity may be in spite of (rather than because of) corruption in the bureaucracy.

Khachatrian also praises Armenia's economy as being one of the best performing ones of the former Soviet Union. National programs of privatization and price liberalization, together with the 2003 accession to the WTO, have been important factors in the economic surge of the country. Khachatrian cites The European Bank for Reconstruction and Development (EBRD) as crediting Armenia as being the most likely candidate among former Soviet Union countries for accession to the EU (doubtless after the accession of other transition countries in 2004 and the scheduled accessions of 2007).

In another article, Khachatrian (2006A) cited a 2005 EBRD announcement that Armenia had joined those former Soviet republics which had regained the GDP level achieved before the disappearance of the USSR. According to EBRD's annual Transition Report, Armenia had fully recovered from the catastrophic 1990s economic decline.

By 2005, only six of 15 former Soviet republics had regained their Soviet-era economic performance level. Uzbekistan was the first, in 2001, followed by Estonia, Turkmenistan, Belarus, Kazakhstan, and then Armenia. One notes that these are generally oil-blessed countries whose new 
independence produced little economic distress. Interestingly Estonia, Latvia and Lithuania joined the EU before they had recovered their previous levels. In 1993 Armenia was still embroiled in the Karabakh War, and the country plunged to only 42 percent of its 1989 GDP. Its remarkable recovery to its current economic double-digit growth (for the fifth consecutive year) attracted the attention of international bodies, including the World Bank, which branded Armenia the "Caucasian Tiger," in spite of its still-low per-capita GDP.

It is both interesting and unfortunate that while this dramatic economic progress has occurred, corruption in Armenia has actually worsened. As reported in Table 3, corruption indices for Armenia exist only for 1999-2000 and for 2003-2006. They demonstrate that very modest improvements early in this decade have not been sustained and that Armenia continues to fall in the country rankings.

Table 3 here

Given the importance of fighting corruption, a Steering Committee has been commissioned under Decree 44, January 22, 2001; by the Prime Minister of the Republic of Armenia to coordinate the anti-corruption program efforts (see Government, 2001). In 2001, the Anti-Corruption Strategy Concept Paper was endorsed by a World Bank grant to devise the Republic of Armenia AntiCorruption Strategy. To this point, however, the strategy has not helped Armenia's performance in the corruption indices. The limited investment and corruption data available are not plentiful enough to be susceptible to econometric analysis, but they confirm our earlier finding that there is no compelling relationship between Foreign Direct Investment and the perceived level of corruption in Armenia. 


\section{Summary and Conclusions}

It has been argued that political corruption represents a significant barrier to economic development, especially in transitional economies. Empirical studies have shown a negative relationship between corruption and GDP growth, which is of particular significance when foreign direct investment is an important factor in development. It is sometimes assumed that investors will tend to avoid corrupt economies due to business uncertainties and the high costs associated with corruption in developing countries. Furthermore, corruption is often present where foreign trade is limited by protectionist policies. We have tested these assumptions through quantitative analysis and with a brief case study of Armenia, whose corruption indices have failed to show consistent progress.

Unfortunately, space and time constraints have made it impossible for us to provide more qualitative impressions of corruption as perceived especially by those who live daily with its effects in Armenia. A recent survey (Armenian Center for National and International Studies, 2004) demonstrated that corruption affects most of the citizens of the country, existing at all spheres and levels of the society. Most citizens of Armenia either have little faith in the government's ability to stop corruption or do not know if it can be stopped. To these citizens, corruption is also just a way of life and a fact of life. But for many of them, it is a costly way of life. Articles in the press are frequent in Armenia, decrying the corruption of state officials, corruption at all levels of government, corruption in the universities and throughout public life.

Our analysis has suggested that corruption acts as a major hindrance for overall economic performance. In the sample of 39 countries for an eleven year period, we found a strong negative correlation between corruption indices and economic performance measured in real per capita GDP. However, when real Foreign Direct Investment indices are regressed on corruption, no strong relationship is found between the two. Thus, while economic growth is reduced by the presence of 
a serious corruption problem, the retardant effect cannot be identified as a function of reduced foreign direct investment. In terms of trade, there is no evidence that high levels of corruption necessarily limit the import of goods and services into the country. On the contrary, imports of goods and services seem to increase as corruption does. This counterintuitive conclusion may suggest that corruption in an economy does not constrain imports, which flow into the country and promote growth in spite of the inconvenience. Increased foreign trade seems simply to provide increased opportunities for low-level, bureaucratic corruption in developing countries. Presumably corruption shifts with economic development away from the "nuisance corruption" of government bureaucracies, where even low-level clerks can be involved. In more developed countries the corruption is more likely to occur at higher levels. In any case, our findings show that corruption negatively impacts growth, although apparently not through the expected channels of foreign investment and trade.

Armenia provides a test of whether corrupt economies continue to receive foreign direct investment or whether FDI declines as a result of higher levels of corruption, as widely assumed. In the case of Armenia, although corruption levels are high and modest progress has not been consistent as measured by Transparency International's Corruption Perception Index, gross fixed investment (which we take as a proxy for FDI - a statistic not provided in Armenia) has increased continually over the past ten years. This strengthens our conclusion that foreign investors do not generally view corruption as a serious threat when planning to invest in a given country. Many firms apparently do not refuse to get involved with corrupt countries, presumably since they view corruption as little more than an inconvenient transactions cost. 


\section{References}

Abed, George T. and Sanjeev Gupta. 2002. "The Economics of Corruption: An Overview” In Governance, Corruption, and Economic Performance, ed. George T. Abed and Sanjeev Gupta, 1-16.

Washington, D.C.: International Monetary Fund, 2002.

Aristidis, Bitzenis. 2003. "Did Financial Incentives Affect Foreign Direct Investment (FDI) Inflows in Bulgaria?” South-Eastern Europe Journal of Economics 1 (Fall): 65-84.

Armenian Center for National and International Studies, 2004, "Corruption in Armenia:

Presentation of Public Opinion Poll Results, September, online at

http:/ / www.google.com/search?q=Corruption + in + Armenia\&start $=0 \& i e=u t f-8 \& o e=u t f-$

8\&client $=$ firefox-a\&rls=org.mozilla:en-US:official

Armenian Tax and Customs Laws, 2006, accessed September, online at

http://www.armeniaemb.org/BusinessEconomy/TaxCustoms/Index.htm.

Bhagwati, Jagdish N. 1982. "Directly Unproductive, Profit-Seeking (DUP) Activities.” Journal of

Political Economy, Vol. 90, No. 5, pp. 1988-1002.

Chambers of Commerce, US and EU. 2003. "A Joint White Paper: Reform of the Armenian Tax

System." The American and European Union Chambers of Commerce in Armenia.

http://www.amcham.am/.

Cheem, Shabbir. 1997. Corruption and Good Governance. Discussion Papers, Bureau for Policy and

Program Support, United Nations Development Program.

Dearden, Stephen. 2000. Corruption and Economic Development. Discussion Paper, Manchester

Metropolitan University, October.

Elliott, Kimberly Ann. 1997. "Corruption as an International Policy Problem: Overview and

Recommendations," in Corruption and the Global Economy, ed. Kimberly Ann Elliott. Washington, D.C.:

Institute for International Economics. 
European Commission. 2005. European Neighbourbood Policy, Recommendations for Armenia, Azerbaijan, Georgia and for Egypt and Lebanon, Brussels, March.

Friedman, Eric et al. 2000. "Dodging the Grabbing Hand: The Determinants of Unofficial Activity in 69 Countries." Journal of Public Economics 77 (June): 459-493.

Glynn, Patrick, Stephen J. Kobrin, and Moises Naim. 1997. “The Globalization of Corruption” In Corruption and the Global Economy, ed. Kimberly Ann Elliott. Washington, D.C.: Institute for International Economics, 7-27.

Goodspeed, Timothy, Jorge Martinez-Vazquez and Li Zhang. 2006. Are Other Government Policies More Important than Taxation in Attracting FDI? Andrew Young School of Policy Studies Research Paper

Series No. 06-28 Available at: http://ssrn.com/abstract $=895150$

Government of the Republic of Armenia. 2001. Republic of Armenia Anti-Corruption Strategy and Implementation Action Plan, http://www.gov.am/enversion/programms_9/korup_prog.htm.

Gray, Cheryl and Daniel Kaufmann, 1998, "Corruption and Development," Finance and Development (March) 7-10.

Gupta, Sanjeev, Hamid Davoodi, and Rosa Alonso-Terme. 1998. Does Corruption Affect Income Inequality and Poverty? IMF Working Papers 98/76. Washington, D. C.

Habib, M. and L. Zurawicki. 2001. "Country-level Investments and the Effect of Corruption -Some Empirical Evidence," International Business Review 10: pp. 687-700.

Huntington, Samuel. 1968. Political Order in Changing Societies. New Haven: Yale Press.

Kaufmann, Daniel. 2000. "Governance and Controlling Corruption is Central for Socio-Economic Development and Growth: New Reports and Evidence." ICPS Roundtable, Kiev, November 6. Khachatrian, Haroutiun. 2006. "New Armenian Economic Plan Targets Poverty." Business and Economics: Eurasia.net, December 30, available at http://www.eurasianet.org/departments/ business/articles/eav062804.shtml. 
Khachatrian, Haroutiun. 2006A. “A 'Tiger' is Born in 15 Years: Armenia:” Armenian General

Benevolent Union, December 21, available at ttp://www.agbu.org/publications/article.asp?A_ID=257

Krueger, Anne O. 1974. "The Political Economy of the Rent-Seeking Society," American Economic

Review 64 (June): 291-303.

Lambsdorff, Johann G. 2003. "How Corruption Affects Persistent Capital Flows.” Economics of

Governance, 4: 18-21.

Leff, N. F. (1989). “Economic Development through Bureaucratic Corruption”. In Political

Corruption: A Handbook. Ed. Arnold J. Heidenheimer, Michael Johnston and Victor T. LeVine. New

Brunswick: Transaction Publishers, 389-403.

Mauro, Paolo. 1997. "The Effects of Corruption on Growth, Investment, and Government

Expenditure: A Cross-Country Analysis." In Corruption and the Global Economy, ed. Kimberly Ann

Elliott, 83-108. Washington, D.C.: Institute for International Economics, 83-108.

Mauro, Paolo. 1995. “Corruption and Growth.” Quarterly journal of Economics 110 (August): 681-712.

Minasian, Sergey. 2005. "EU-Armenia Cooperation and The New European Neighborhood Policy."

International IDEA: pp. 21-31.

Rose-Ackerman, Susan. 1978. Corruption: a study in political economy. New York: Academic Press, 1978.

Tsaghikyan, Stepan. 2002. Corruption: Reasons, Consequences. Yerevan: Antares.

Tullock, Gordon. 1989. The Economics of Special Privilege and Rent Seeking, Boston: Kluwer Academic

Publishers.

Wacziarg, Romain. 2002. "Review of Easterly's The Elusive Quest for Growth,” Journal of Economic

Literature XL (September): 907-918. 
Figure 1

\section{Corruption and Capital Inflows by Lambsdorff}

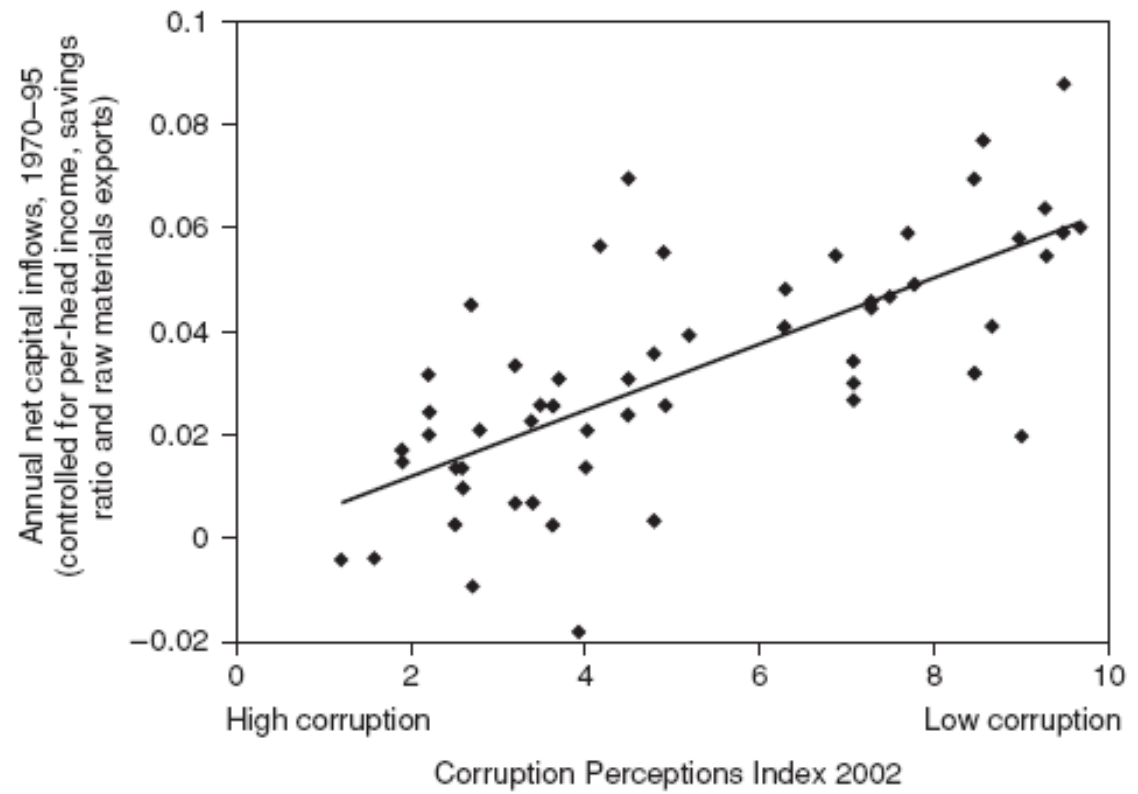

Source: Lambsdorff, p. 311 
Figure 2

\section{GDP Regressed on the Corruption Index}

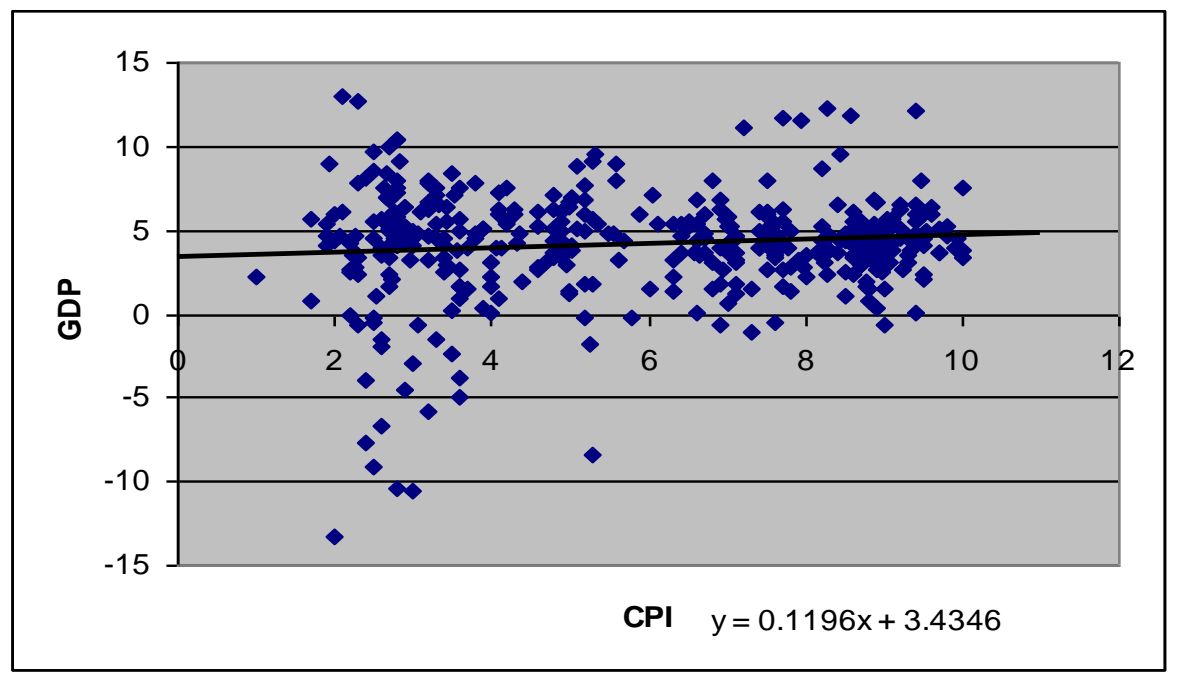


Figure 3

Imports of Goods and Services Regressed on the Corruption Index

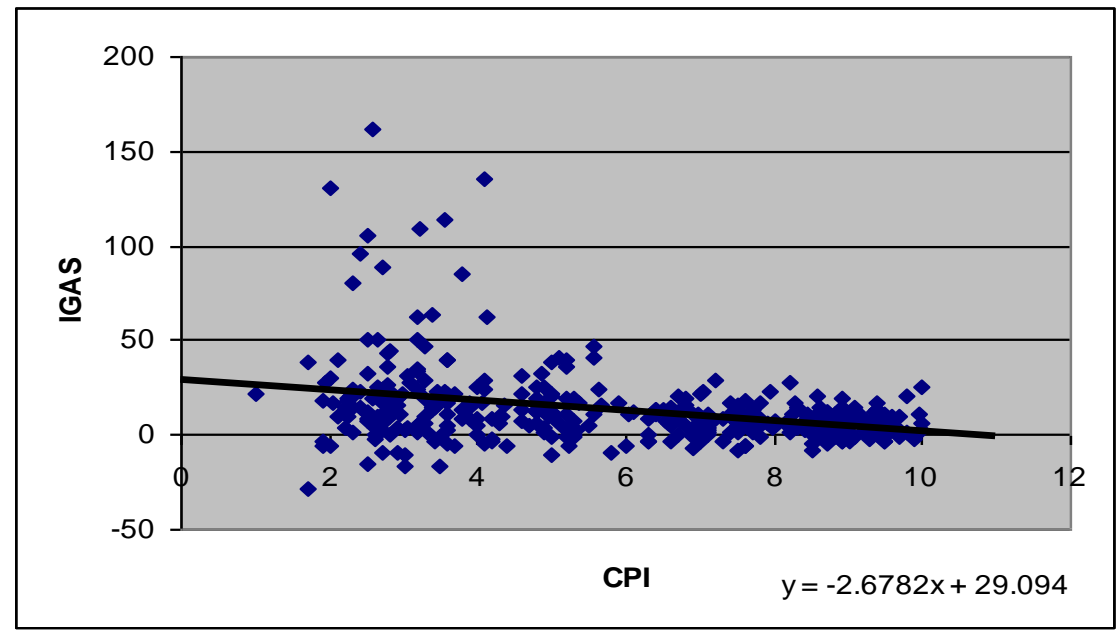


Table 1

\begin{tabular}{|c|c|c|c|c|c|c|c|c|c|}
\hline \multicolumn{10}{|c|}{$\begin{array}{c}\text { Pearson Correlation Coefficients, } \mathrm{N}=390 \\
\text { Prob }>|\mathrm{r}| \text { under H0: } \mathrm{Rho}=\mathbf{0}\end{array}$} \\
\hline & FDII & GDP & GFCE & GFCF & Imports & IGAS & IS & PFCE & RGDP \\
\hline FDII & 1.00000 & -0.02576 & 0.00873 & 0.11755 & -0.02289 & 0.13297 & 0.02158 & 0.13506 & -0.03453 \\
\hline FDII & & 0.6121 & 0.8636 & 0.0202 & 0.6522 & 0.0086 & 0.6709 & 0.0076 & 0.4965 \\
\hline GDP & -0.02576 & 1.00000 & 0.01880 & 0.34458 & 0.59097 & 0.11546 & -0.07994 & 0.02139 & 0.92910 \\
\hline GDP & 0.6121 & & 0.7114 & $<.0001$ & $<.0001$ & 0.0226 & 0.1150 & 0.6736 & $<.0001$ \\
\hline GFCE & 0.00873 & 0.01880 & 1.00000 & 0.19075 & 0.10368 & 0.15572 & -0.05596 & 0.16479 & 0.01727 \\
\hline GFCE & 0.8636 & 0.7114 & & 0.0002 & 0.0407 & 0.0020 & 0.2702 & 0.0011 & 0.7339 \\
\hline GFCF & 0.11755 & 0.34458 & 0.19075 & 1.00000 & 0.40934 & 0.82135 & -0.04554 & 0.81047 & 0.39212 \\
\hline GFCF & 0.0202 & $<.0001$ & 0.0002 & & $<.0001$ & $<.0001$ & 0.3698 & $<.0001$ & $<.0001$ \\
\hline Imports & -0.02289 & 0.59097 & 0.10368 & 0.40934 & 1.00000 & 0.24924 & -0.10483 & 0.15361 & 0.60790 \\
\hline Imports & 0.6522 & $<.0001$ & 0.0407 & $<.0001$ & & $<.0001$ & 0.0385 & 0.0024 & $<.0001$ \\
\hline IGAS & 0.13297 & 0.11546 & 0.15572 & 0.82135 & 0.24924 & 1.00000 & -0.05725 & 0.86259 & 0.15586 \\
\hline IGAS & 0.0086 & 0.0226 & 0.0020 & $<.0001$ & $<.0001$ & & 0.2594 & $<.0001$ & 0.0020 \\
\hline IS & 0.02158 & -0.07994 & -0.05596 & -0.04554 & -0.10483 & -0.05725 & 1.00000 & -0.04190 & -0.12167 \\
\hline IS & 0.6709 & 0.1150 & 0.2702 & 0.3698 & 0.0385 & 0.2594 & & 0.4093 & 0.0162 \\
\hline PFCE & 0.13506 & 0.02139 & 0.16479 & 0.81047 & 0.15361 & 0.86259 & -0.04190 & 1.00000 & 0.06539 \\
\hline PFCE & 0.0076 & 0.6736 & 0.0011 & $<.0001$ & 0.0024 & $<.0001$ & 0.4093 & & 0.1975 \\
\hline RGDP & -0.03453 & 0.92910 & 0.01727 & 0.39212 & 0.60790 & 0.15586 & -0.12167 & 0.06539 & 1.00000 \\
\hline RGDP & 0.4965 & $<.0001$ & 0.7339 & $<.0001$ & $<.0001$ & 0.0020 & 0.0162 & 0.1975 & \\
\hline
\end{tabular}


Table 2

GDP, Imports, FDI and the Corruption Perception Index

\begin{tabular}{|c|c|c|c|c|c|}
\hline \multicolumn{6}{|c|}{ Significant Models: } \\
\hline \multicolumn{6}{|c|}{ GDP regressed on $\mathrm{CPI}$} \\
\hline \multicolumn{6}{|c|}{ Solution for Fixed Effects } \\
\hline Effect & Estimate & S.E. & $\mathrm{DF}$ & t Value & $\operatorname{Pr}>|\mathrm{t}|$ \\
\hline Intercept & 3.4346 & 0.4099 & 38 & 8.38 & $<.0001$ \\
\hline CPI & 0.1196 & 0.06418 & 350 & 1.86 & 0.0633 \\
\hline \multicolumn{6}{|c|}{ Imports of Goods and Services regressed on CPI } \\
\hline \multicolumn{6}{|c|}{ Solution for Fixed Effects } \\
\hline Effect & Estimate & S.E. & $\mathrm{DF}$ & t Value & $\operatorname{Pr}>|t|$ \\
\hline Intercept & 29.0940 & 2.4389 & 38 & 11.93 & $<.0001$ \\
\hline CPI & -2.6782 & 0.3819 & 350 & -7.01 & $<.0001$ \\
\hline \multicolumn{6}{|c|}{ Non-Significant Models : } \\
\hline \multicolumn{6}{|c|}{ FDII regressed on CPI } \\
\hline \multicolumn{6}{|c|}{ Solution for Fixed Effects } \\
\hline Effect & Estimate & S.E. & $\mathrm{DF}$ & t Value & $\operatorname{Pr}>|\mathrm{t}|$ \\
\hline Intercept & 54.2042 & 22.1498 & 38 & 2.45 & 0.0191 \\
\hline CPI & -0.4845 & 3.4681 & 350 & -0.14 & 0.8890 \\
\hline \multicolumn{6}{|c|}{ Imports regressed on CPI } \\
\hline \multicolumn{6}{|c|}{ Solution for Fixed Effects } \\
\hline Effect & Estimate & S.E. & $\mathrm{DF}$ & t Value & $\operatorname{Pr}>|t|$ \\
\hline Intercept & 10.0892 & 1.9034 & 38 & 5.30 & $<.0001$ \\
\hline CPI & -0.3940 & 0.2980 & 350 & -1.32 & 0.1870 \\
\hline
\end{tabular}


Table 3

\begin{tabular}{|l|r|r|r|l|r|r|r|c|}
\hline & \multicolumn{1}{|c|}{1999} & $\mathbf{2 0 0 0}$ & $\mathbf{2 0 0 1}$ & $\mathbf{2 0 0 2}$ & $\mathbf{2 0 0 3}$ & $\mathbf{2 0 0 4}$ & $\mathbf{2 0 0 5}$ & $\mathbf{2 0 0 6}$ \\
\hline Armenia & 2.50 & 2.50 & NA. & NA & 3.00 & 3.10 & 2.90 & 2.90 \\
\hline Ranking & 80 & 76 & NA. & NA & 78 & 82 & 88 & 93 \\
\hline
\end{tabular}

Source: Table data compiled from the Transparency International's Corruption Perception Index. Available at: http://www.transparency.org/policy_research/surveys_indices/cpi/2006 


\section{Appendix}

\section{Table X: 1}

\section{Corruption Perception Index by Transparency International}

\begin{tabular}{|c|c|c|c|c|c|c|c|c|c|c|c|}
\hline Country & 1995 & 1996 & 1997 & 1998 & 1999 & 2000 & 2001 & 2002 & 2003 & 2004 & 2005 \\
\hline Argentina & 5.24 & 3.41 & 2.81 & 3.00 & 3.00 & 3.50 & 3.50 & 2.80 & 2.50 & 2.50 & 2.80 \\
\hline Armenia** & & & & & 2.50 & 2.50 & & & 3.00 & 3.10 & 2.90 \\
\hline Australia & 8.80 & 8.60 & 8.86 & 8.70 & 8.70 & 8.30 & 8.50 & 8.60 & 8.80 & 8.80 & 8.80 \\
\hline Austria & 7.13 & 7.59 & 7.61 & 7.50 & 7.60 & 7.70 & 7.80 & 7.80 & 8.00 & 8.40 & 8.70 \\
\hline Bolivia & $3.4^{*}$ & 3.40 & 2.05 & 2.80 & 2.50 & 2.70 & 2.00 & 2.20 & 2.30 & 2.20 & 2.50 \\
\hline Brazil & 2.70 & 2.96 & 3.56 & 4.00 & 4.10 & 3.90 & 4.00 & 4.00 & 3.90 & 3.90 & 3.70 \\
\hline Canada & 8.87 & 8.96 & 9.10 & 9.20 & 9.20 & 9.20 & 8.90 & 9.00 & 8.70 & 8.50 & 8.40 \\
\hline Chile & 7.94 & 6.80 & 6.05 & 6.80 & 6.90 & 7.40 & 7.50 & 7.50 & 7.40 & 7.40 & 7.30 \\
\hline Colombia & 3.44 & 2.73 & 2.23 & 2.20 & 2.90 & 3.20 & 3.80 & 3.60 & 3.70 & 3.80 & 4.00 \\
\hline Denmark & 9.32 & 9.33 & 9.94 & 10.00 & 10.00 & 9.80 & 9.50 & 9.50 & 9.50 & 9.50 & 9.50 \\
\hline Finland & 9.12 & 9.05 & 9.48 & 9.60 & 9.80 & 10.00 & 9.90 & 9.70 & 9.70 & 9.70 & 9.60 \\
\hline France & 7.00 & 6.96 & 6.66 & 6.70 & 6.60 & 6.70 & 6.70 & 6.30 & 6.90 & 7.10 & 7.50 \\
\hline Germany & 8.14 & 8.27 & 8.23 & 7.90 & 8.00 & 7.60 & 7.40 & 7.30 & 7.70 & 8.20 & 8.20 \\
\hline Greece & 4.04 & 5.01 & 5.35 & 4.90 & 4.90 & 4.90 & 4.20 & 4.20 & 4.30 & 4.30 & 4.30 \\
\hline Hungary & 4.12 & 4.86 & 5.18 & 5.00 & 5.20 & 5.20 & 5.30 & 4.90 & 4.80 & 4.80 & 5.00 \\
\hline India & 2.78 & 2.63 & 2.75 & 2.90 & 2.90 & 2.80 & 2.70 & 2.70 & 2.80 & 2.80 & 2.90 \\
\hline Indonesia & 1.94 & 2.65 & 2.72 & 2.00 & 1.70 & 1.70 & 1.90 & 1.90 & 1.90 & 2.00 & 2.20 \\
\hline Ireland & 8.57 & 8.45 & 8.28 & 8.20 & 7.70 & 7.20 & 7.50 & 6.90 & 7.50 & 7.50 & 7.40 \\
\hline Israel & $7.71 *$ & 7.71 & 7.97 & 7.10 & 6.80 & 6.60 & 7.60 & 7.30 & 7.00 & 6.40 & 6.30 \\
\hline Italy & 2.99 & 3.42 & 5.03 & 4.60 & 4.70 & 4.60 & 5.50 & 5.20 & 5.30 & 4.80 & 5.00 \\
\hline Japan & 6.72 & 7.05 & 6.57 & 5.80 & 6.00 & 6.40 & 7.10 & 7.10 & 7.00 & 6.90 & 7.30 \\
\hline Malaysia & 5.28 & 5.32 & 5.01 & 5.30 & 5.10 & 4.80 & 5.00 & 4.90 & 5.20 & 5.00 & 5.10 \\
\hline Mexico & 3.18 & 3.30 & 2.66 & 3.30 & 3.40 & 3.30 & 3.70 & 3.60 & 3.60 & 3.60 & 3.50 \\
\hline Netherlands & 8.69 & 8.71 & 9.03 & 9.00 & 9.00 & 8.90 & 8.80 & 9.00 & 8.90 & 8.70 & 8.60 \\
\hline N. Zealand & 9.55 & 9.43 & 9.23 & 9.40 & 9.40 & 9.40 & 9.40 & 9.50 & 9.50 & 9.60 & 9.60 \\
\hline Norway & 8.61 & 8.87 & 8.92 & 9.00 & 8.90 & 9.10 & 8.60 & 8.50 & 8.80 & 8.90 & 8.90 \\
\hline Pakistan & 2.25 & 1.00 & 2.53 & 2.70 & 2.20 & $2.25^{*}$ & 2.30 & 2.60 & 2.50 & 2.10 & 2.10 \\
\hline Philippines & 2.77 & 2.69 & 3.05 & 3.30 & 3.60 & 2.80 & 2.90 & 2.60 & 2.50 & 2.60 & 2.50 \\
\hline Poland & $5.57 *$ & 5.57 & 5.08 & 4.60 & 4.20 & 4.10 & 4.10 & 4.00 & 3.60 & 3.50 & 3.40 \\
\hline Portugal & 5.56 & 6.53 & 6.97 & 6.50 & 6.70 & 6.40 & 6.30 & 6.30 & 6.60 & 6.30 & 6.50 \\
\hline Russia & $2.58^{*}$ & 2.58 & 2.27 & 2.40 & 2.40 & 2.10 & 2.30 & 2.70 & 2.70 & 2.80 & 2.40 \\
\hline S. Africa & 5.62 & 5.68 & 4.95 & 5.20 & 5.00 & 5.00 & 4.80 & 4.80 & 4.40 & 4.60 & 4.50 \\
\hline Spain & 4.35 & 4.31 & 5.90 & 6.10 & 6.60 & 7.00 & 7.00 & 7.10 & 6.90 & 7.10 & 7.00 \\
\hline Sweden & 8.87 & 9.08 & 9.35 & 9.50 & 9.40 & 9.40 & 9.00 & 9.30 & 9.30 & 9.20 & 9.20 \\
\hline Switzerland & 8.76 & 8.76 & 8.61 & 8.90 & 8.90 & 8.60 & 8.40 & 8.50 & 8.80 & 9.10 & 9.10 \\
\hline Thailand & 2.79 & 3.33 & 3.06 & 3.00 & 3.20 & 3.20 & 3.20 & 3.20 & 3.30 & 3.60 & 3.80 \\
\hline Turkey & 4.10 & 3.54 & 3.21 & 3.40 & 3.60 & 3.80 & 3.60 & 3.20 & 3.10 & 3.20 & 3.50 \\
\hline UK & 8.57 & 8.44 & 8.22 & 8.70 & 8.60 & 8.70 & 8.30 & 8.70 & 8.70 & 8.60 & 8.60 \\
\hline USA & 7.79 & 7.66 & 7.61 & 7.50 & 7.50 & 7.80 & 7.60 & 7.70 & 7.50 & 7.50 & 7.60 \\
\hline Venezuela & 2.66 & 2.50 & 2.77 & 2.30 & 2.60 & 2.70 & 2.80 & 2.50 & 2.40 & 2.30 & 2.30 \\
\hline
\end{tabular}

*Those numbers were roughly estimated for our regression, and do not appear in the actual Transparency Index. ** Armenia is not included in our analysis due to the lack of data. 